Paedagogia Christiana

I/29 (2012) - ISSN 1505-6872

Marian Nowak ${ }^{*}$

Lublin

\title{
Czy wychowanie bez celu?
}

Specyfika sytuacji człowieka (jej antropologiczne i aksjologiczne oraz ontologiczne podstawy) wyraźnie wyodrębniają egzystencję ludzką od tej innych istot żywych. Człowiek nie potrafi przeżyć (czyli zachować życie) jak to jest możliwe na przykład w przypadku zwierząt, działając tylko w ramach odpowiadania na potrzeby chwili i w kontakcie z bezpośrednią rzeczywistością, lecz potrzebuje perspektywy własnej egzystencji - tej biegnącej ku przyszłości i tej zachowującej pamięć przeszłości. Nade wszystko potrzebuje on projektowania swoich celów, które osiąga lub będzie mógł osiągać w dłuższym lub krótszym czasie.

Wskazuje się często też na odkrywaną w biografiach ludzkich prawidłowość, że im bardziej rozbudzony umysł człowieka, im większa jest jego wiedza, tym dalszy jest zakres jego planowania. Ma to swoje przełożenie także na społeczne konteksty życia, a mianowicie podkreśla się, że im wyższe i bardziej złożone jest życie danych społeczności, tym bardziej wymagają one szerszego i bardziej złożonego ujęcia zakresu ich aktywności, jak również pewniejszego i poszerzonego zakresu wzajemnych zobowiązań i paktów. Domagają się też one większych i pewniejszych zabezpieczeń dla umów i paktów zawieranych między osobami i grupami porozumień ${ }^{1}$.

Tak w wymiarze jednostkowym, jak i społecznym swojej egzystencji człowiek potrzebuje jednak nie tylko tego rodzaju uregulowań prawnych

* Ks. prof. dr hab. Marian Nowak - dyrektor Instytutu Pedagogiki Katolickiego Uniwersytetu Lubelskiego Jana Pawła II.

${ }^{1}$ A. Rand, Collectivized „Rights”, w: tenże, The Virtue of Selfishness. A New Concept of Egoism, New York 1970, s. 129-130n. 
i formalnych, lecz nade wszystko oparcia się na pewnej stałości i wzniosłości natury duchowej, czyli na pewnych wartościach. Tak otwiera się stawiany $\mathrm{w}$ obecnym artykule problem, wyrażony w formie pytania: Czy wychowanie bez celu? A skoro mowa o celu, to konieczne staje się odniesienie się do wartości. Czym jednak są wartości? Jak one istnieją? Skąd pochodzą?

W odpowiedzi na te pytania możemy przywołać często wymieniane trzy stanowiska związane już od starożytności z zastanawianiem się, skąd ludzie wiedzą o dobru? Pierwsze stanowisko wiązane było z odpowiedzią starożytnych, że to bogowie Olimpu powiedzieli nam o dobru. Drugie stanowisko wiązano ze wskazaniem na ludzkie doświadczenie wartości, a zatem, sami ludzie doświadczali dobra i do niego dążyli? Chrześcijaństwo reprezentuje w tej dyskusji trzecie, pośrednie stanowisko, zauważając i akcentując z jednej strony Prawo Boże (Przykazania) dane nam „z góry”, ale z drugiej strony zauważamy też odwoływanie się do ludzkiego doświadczenia. Przykład takiego podejścia daje sam Jezus Chrystus. Między innymi w Przypowieści o mitosiernym Samarytaninie możemy zauważyć, jak z jednej strony odwołuje się do przykazań i wskazuje na potrzebę ich zachowywania, a zwłaszcza odnosi się do przykazania miłości Boga i bliźniego, z drugiej strony Jezus odwołuje się do doświadczenia ludzi, przytaczając dla wyobraźni swoich słuchaczy historię miłosiernego Samarytanina i człowieka pobitego przez zbójców. Na pytanie uczonego w Piśmie: „Kto jest moim bliźnim?”- odpowiada obrazowo, zarysowując $\mathrm{w}$ formie przypowieści doświadczenie możliwego postępowania ludzi wobec tego, który wpadł w ręce zbójców i w stanie człowieka na wpót żywego został pozostawiony przez nich przy drodze.

Kto może być obdarzony wartościami?

Odpowiedź na to pytanie możemy zacząć od stwierdzenia ogólnie uznawanego, że nie ma ludzi niekierujących się wartościami. W istocie cały problem i nieporozumienia tkwią nie tyle w tym, że ktoś chce coś osiągnąć, że dochodzi swoich spraw i chce poprawić swoją sytuację, ktoś chce lepiej wiedzieć - więc się uczy, ale też chce więcej zarobić, lepiej prosperować itd. Istota problemu leży natomiast $\mathrm{w}$ tym, co dany człowiek widzi jako największą własną wartość. Nie tyle zatem ważne jest stwierdzanie o fakcie, że ktoś zabiega o jakieś wartości, lecz o jakie wartości i w czym on te wartości dostrzega? Nie tyle jest ważne, że ktoś opowiada się za życiem, za pomyślnością, za wellness, ile czy kształt tego życia, za jakim się opowiada, jest jeszcze ludzki?²

Ale czy cele są konieczne w ogóle dla człowieka? A jeśli już widziane są jako konieczne dla człowieka, to i dla jego wychowania. Wielokrotnie powtarzane stwierdzenie, że nie ma wychowania ani nauczania bez wartości

\footnotetext{
${ }^{2}$ Zob. tenże, Introduction, w: tenże, The Virtue, s. VII-IXn.
} 
i bez celów, ma pełne swoje uzasadnienie w praktyce życia. Jeśli kogoś wychowuję lub chcę czegoś nauczyć, to stawiam cele i wartościuję - wcześniejszy stan uznając za gorszy od tego, jaki proponuję jako pewne dobro. Na ten temat zabierają głos także teoretycy i badacze natury ludzkiej, do których przykładowo jedynie chcemy się odwołać.

Nie brakuje wśród współczesnego spectrum teorii i koncepcji antropologicznych takich, które analizując na przykład psychiczną kondycję człowieka i w ogóle dotykając podstawowych prawidłowości jego życia, wskazują na charakteryzującą naturę ludzką celowość. Mówi o tym między innymi teoria psychologii indywidualnej Alfreda Adlera, od której chcę rozpocząć obecną prezentację.

\section{Dążenie czlowieka do celu jako podstawowe założenie psychologii indywidualnej Alfreda Adlera}

Społeczny i celowościowy kontekst życia i funkcjonowania człowieka akcentuje teoria Alfreda Adlera (1870-1937), początkowo przyjaciela Freuda (za jego wskazaniem wybrany na przewodniczącego Towarzystwa Psychoanalityków w Austrii), lecz różnice poglądów, a zwłaszcza dążenia Freuda, by całość zachowań oprzeć na instynkcie seksualnym, doprowadziły do zerwania tej przyjaźni i ukierunkowania się Adlera na trochę inną drogę interpretacyjną ${ }^{3}$.

Adler wywarł chyba najbardziej istotny wpływ na rozwój kognitywnego podejścia terapeutycznego $\mathrm{w}$ takich współczesnych teoriach, jak na przykład realistyczna terapia, egzystencjalna praca socjalna, analityczna terapia kognitywna, kognitywna terapia Becka czy Elissa. Już w okresie swojego powstawania teoria planów życiowych Adlera i koncepcja indywidualnego stylu życia każdej jednostki wydawała się bardzo przekonująca, podobnie jak wychowawcza rola procesów kompensacyjnych, wspieranych wrodzonym instynktem społecznym (poczuciem wspólnoty) ${ }^{4}$.

W odróżnieniu od psychoanalizy, która usiłuje stosować wyjaśnianie przyczynowe i poszukuje przyczyn aktualnej postawy człowieka w jego nierozwiązanych problemach i frustracjach, zwłaszcza z okresu wczesnego dzieciństwa, psychologia indywidualna wskazuje na cel, do którego każdy człowiek w swoim życiu dąży. Życie ludzkie jest pojmowane jako zorientowane na cel. Dobrze to stanowisko Adlera i oryginalność jego teorii wyraża

${ }^{3}$ Z. Płużek, Psychologia pastoralna, Kraków 1991, s. 20-23.

${ }^{4}$ Zob. S. Wołoszyn, Nauki o wychowaniu w Polsce w XX wieku, Warszawa 1992, s. 48 . 
stwierdzenie: czlowiek działa ze względu na stawiany sobie cel. Tego rodzaju wyjaśnianie nazywane jest finalnym lub docelowym.

W tym też sensie wskazuje się, że jeśli rozpoznamy cel, do jakiego dany człowiek zdąża, będziemy mogli poznać jego zamiary, jego postawę i interpretować jego działanie. Widząc dziecko wspinające się na szafę, możemy zrozumieć jego zachowanie, obserwując jego dążenie do ściągnięcia siedzącej na szafie lalki. Uwzględniając także przyczyny prowadzące do określonych zachowań, psychologia indywidualna bada, co z tym wszystkim dana jednostka robi i na jaki cel je skieruje. Cel ten nie zawsze jest przez jednostkę uświadomiony, ale jest on zawsze podstawą jej orientacji w świecie ${ }^{5}$.

Dążenie człowieka do celu zostało uznane przez Adlera za podstawową zasadę jedności osobowości: każdy organizm to zamknięta w sobie całość, którą jest właśnie indywidualność (stąd także nazwa tego podejścia teoretycznego - psychologia indywidualna). Żadnej postawy człowieka nie można rozpatrywać w sensie wyizolowanym, lecz właśnie przez odniesienie się do całej osobowości. Dlatego też indywidualna psychologia często mówi o stylu życia, wyznaczanym przez opinię jednostki o sobie i świecie oraz przez sposób, w jaki dana jednostka dąży do swoich celów. A skoro wychowanie jest zintegrowaniem osobowości wychowanka, więc nie byłoby ono możliwe bez postawienia sobie celów.

Styl życia według psychologii indywidualnej odzwierciedla jedność osobowości i powinien być zawsze widziany jako złączony z pewnymi uwarunkowaniami otoczenia, a ostatecznie jako rezultat tego, co człowiek w sposób świadomy i nieświadomy czyni ze swoich predyspozycji i doświadczeń, które właśnie sprawiają, że dana jednostka odróżnia się od innych. Reprezentuje on zatem indywidualność i spójność osobowości człowieka i jako taki jest on formowany już we wczesnym dzieciństwie. Tę właśnie jedność i spójność osobowości nazywamy stylem życia jednostki. Dla wyjaśnienia natomiast jakiegoś zachowania lub jego zmiany nie wystarczy opierać się na jakimś odosobnionym zachowaniu, lecz należy zmierzać do odkrycia całego stylu życia jednostki ${ }^{6}$.

Punktem wyjścia rozwoju jednostki jest poczucie małowartościowości, które - według psychologii indywidualnej - wiąże się z nieprzyjemnym doświadczaniem własnych niedociągnięć i bycia podporządkowanym innym. Wiąże się z tym zwykle bardzo niskie poczucie własnej wartości, prowadzące do podporządkowania się innym. Taki stan może wynikać z poczucia

${ }^{5}$ Zob. H. L. Ansbacher, R. R. Ansbacher, Alfred Adlers Individualpsychologie, München-Basel 1972.

${ }^{6}$ Zob. Z. Płużek, dz. cyt., s. 23-25; H. Hobmair (Hrsg.), Pädagogik, Köln-München 1989, s. 124-126. 
niespełniania wymagań stawianych w ramach standardów w danej grupie społecznej lub z lęku społecznego wobec jakiejś oceny społecznej, jaka może zapaść i wiązać się z niższą pozycją społeczną lub wykluczeniem ze społeczności i w rezultacie wyobcowaniem ze społeczeństwa ${ }^{7}$.

Poczucie małowartościowości powstaje zwykle u dziecka, które w kontakcie z otoczeniem, zwłaszcza z dorosłymi, doświadcza, jak wielu rzeczy jeszcze nie potrafi i w jak wielu rzeczach jest zależne od innych, jak wiele jeszcze musi ćwiczyć i jak wiele jeszcze się uczyć. Chodzi zatem o swoiste kulturowe i cywilizacyjne zniechęcenie powstające u młodego człowieka, uwarunkowane najczęściej odkryciem społecznych zadań, wobec jakich każdy staje. Według psychologii indywidualnej jest to podstawowe doświadczenie każdego człowieka i jest podstawa rozwoju, a nawet może być rozpatrywane jako w ogóle podstawa wychowalności człowieka ${ }^{8}$.

$Z$ tych też racji rozróżnia się zdrowe poczucie małowartościowości, pełne nadziei u tego, który jeszcze w tej chwili nie potrafi czegoś wykonać, ale co wydaje się możliwe do przezwyciężenia, jak również poczucie określane jako kompleks małowartościowości, związane z przedłużającymi się sytuacjami nieradzenia sobie z wyzwaniami życia, ze spiętrzeniem się przeszkód i lęków ${ }^{9}$.

Jednostka nie pozostaje oczywiście obojętna wobec własnego poczucia małej wartości, lecz poszukuje jego kompensacji, spychając je do podświadomości lub też poszukując dróg i sposobów przezwyciężenia tej sytuacji.

Według psychologii indywidualnej kryterium zdrowego lub neurotycznego rozwoju jest tak zwane poczucie wspólnoty (zmysł społeczny), który oznacza rozwiniętą, wrodzoną gotowość odpowiadania na wymagania życia społecznego i wspólnotowego. Jest to możliwość wrodzona, w sensie zdolności i gotowości tkwiącej w człowieku, która dzięki wychowaniu może być doskonalona i rozwijana. Wiąże się to poczucie z doświadczaniem przynależności, świadomością pozostawania w związkach z innymi ludźmi i dzielenia z nimi ich sytuacji życiowych, jak również z otwartością i gotowością do wchodzenia $\mathrm{w}$ relacje $\mathrm{z}$ innymi i współpracy $\mathrm{z}$ innymi ${ }^{10}$.

Sytuacją egzystencjalną człowieka jest wspólne życie z innymi i wpisanie w rzeczywistość społeczną, z którą wiąże się także poczucie własnej wartości. W istocie człowiek, który nie wyraził swojego poczucia wspólnoty, nie potrafi też odpowiadać w sposób właściwy na wyzwania życia

${ }^{7}$ Zob. H. Hobmair (Hrsg.), dz. cyt., s. 126-127; F. Novak (i in.), Pädagogik 1: Grundwissen, München 1976, s. 120.

${ }^{8}$ Zob. F. Novak (i in.), dz. cyt., s. 119-120; H. Hobmair (Hrsg.), dz. cyt., s. 128-129.

${ }^{9}$ Zob. H. Hobmair (Hrsg.), dz. cyt., s. 126-128.

${ }^{10}$ Zob. W. Metzger, Psychologie in der Erziehung, Bochum 1971. 
społecznego i nie znajduje rozwiązania swoich problemów. Nie potrafi on też budować właściwego poczucia własnej wartości i w efekcie nie osiąga swoich celów. W tym momencie zatem możemy widzieć dwie możliwości kompensacji własnego poczucia małowartościowości, którego rozwój może biec „ku górze” i we współpracy z innymi prowadzić do osiągania celów, lub też, w przypadku jednostek neurotycznych, może wystąpić koncentracja na samym sobie i własnych celach, które nie uwzględniają celów społecznych.

Ponieważ wychowanie stawia sobie za zadanie wspieranie indywidualnego i społecznego rozwoju człowieka, powinno umożliwiać wychowankowi utrzymywanie się ustawiczne w sytuacji pełnego nadziei spojrzenia na przyszłe perspektywy rozwoju i osiągania celów społecznie cenionych i wartościowanych wysoko w danej społeczności. Skoro ma być ono ofertą społecznej pomocy, aby wychowanek odpowiadał na wyzwania życia społecznego i dochodził do zdrowego poczucia własnej wartości, sympatia i życzliwość, atmosfera serdeczności i klimat emocjonalnego ciepła powinny się stawać ważnym wskazaniem co do możliwości obudzenia w wychowanku i podjęcia przez niego wysiłku wyrażania zmysłu przynależności i poczucia wspólnotowości, a w istocie budzenia i wzmacniania motywacji wychowanka ${ }^{11}$.

Wydaje się też, że właśnie teoria psychologii indywidualnej może stanowić ważne wskazanie w związku z potrzebą celów w wychowaniu i niemożliwością realizowania wychowania w przypadku odejścia od problematyki celów i od celowości ${ }^{12}$.

\section{Etyczne i antropologiczne interpretacje kondycji czlowieka jako źródła celów wychowania}

Dotychczasowe analizy problematyki wartości w naukach o wychowaniu, czy ogólnie mówiąc w pedagogice, wskazywały na więź tej problematyki z człowiekiem i jego egzystencją. Jest to więź na tyle istotna, że pozwala mówić o pedagogice $\mathrm{w}$ kategoriach antropologii pedagogicznej ${ }^{13}$, ale też wyróżniać w pedagogice dyscyplinę stanowiącą czasami dział pedagogiki ogólnej lub określone jej ujęcie, czasami zaś jako odrębną naukę o wychowaniu - istotną w wyznaczaniu celów i wartości dla wychowania

11 Zob. M. Nowak, Teorie i koncepcje wychowania, Warszawa 2008, s. 354-357.

12 Zob. B. D. Starr, H. S. Goldstein, Human Development and Behavior, New York 1975, s. 194-195; H. Hobmair (Hrsg.), dz. cyt., s. 138-150.

${ }^{13}$ H. Roth, Pädagogische Anthropologie, Bd. 1: Bildsamkeit und Bestimmung, Hannover 1971; Bd. 2: Entwicklung und Erziehung, Hannover 1971; zob. także K. Ablewicz, Teoretyczne i metodologiczne podstawy pedagogiki antropologicznej, Kraków 2003. 
oraz w budowaniu koncepcji wychowania ${ }^{14}$. Osadzenie tych wartości i celowości życia i działalności człowieka jest jednak antropologiczne (posiadają one antropologiczne pochodzenie i charakter). Czasami jednak próbuje się tego osadzenia szukać gdzieś indziej.

Według Romany Miller, cele wychowania zależą od ideologii społeczeństwa, gdyż wychowanie wyrasta z życia społecznego oraz służy jego rozwojowi. Osoby w procesie wychowania podlegają społeczeństwu. Daje ona jednak ważne wskazanie związane z tym, że źródła celów wychowania można upatrywać także w naturze ludzkiej.

W tym właśnie znaczeniu, według B. Suchodolskiego, źródłem celów wychowania może być koncepcja człowieka i humanistyczny charakter cywilizacji. Autor ten wyróżnił trzy rodzaje koncepcji człowieka:

1. Koncepcja ontologiczna i metafizyczna - określa człowieka jako byt osobowy i konkretny.

2. Koncepcja empiryczna - wskazuje na potrzebę badania tej rzeczywistości, jaką jest człowiek, i z wyników tych badań wyprowadza wnioski dla wychowania.

3. Koncepcja materialistyczna - ujmuje człowieka jako istotę aktywną, stwarzającą rzeczywistość i siebie.

Zrozumienie tego, kim jest człowiek, było celem wysiłków wielu epok i wielu badaczy. W historii tych poszukiwań ukształtowały się między innymi koncepcje człowieka jako: l’hômme machine (człowiek maszyna), homo sapiens (człowiek myślący), homo oeconomicus (człowiek, którego wartość mierzona jest tym, co posiada), homo creator (człowiek twórca), homo faber - homo laborans (człowiek pracownik); homo Dei (człowiek Boży) ${ }^{15}$.

Człowiek bowiem w świadomości samego siebie poszukuje doświadczenia swojego życia. Jeśli ta świadomość potrafi być krytyczna - dzięki myśleniu, potrafi odrzucić wartości fałszywe i poszukiwać prawdziwych wartości życiowych. Człowiek formujący samego siebie w swoim człowieczeństwie, poszukuje w najgłębszej swojej ludzkiej istocie uczucia dającego podstawę wartościom, które z kolei stają się jego możliwością życia i sposobem ludzkiego bycia człowieka ${ }^{16}$.

Sens wartości polega na ich znaczeniu. Tylko też ludzkość i człowieczeństwo w człowieku może w całkowitej wolności od wszelkich układów, władz czy tradycji, potwierdzić znaczenie i wagę wszelkich wartości

${ }^{14}$ M. Nowak, Od filozofii człowieka do filozofii wychowania, w: H. Kwiatkowska (red.), Ewolucja tożsamości pedagogiki, Warszawa 1994, s. 120-135.

${ }^{15}$ Zob. B. Suchodolski, Świat humanistyczny, „Kwartalnik Pedagogiczny” 2 (1985), s. 73; zob. także A. Molesztak, Cele wychowania. W poszukiwaniu istoty $i$ źródet stanowienia, w: A. Tchorzewski (red.), Wychowanie w kontekście teoretycznym, Bydgoszcz 1993, s. 86.

${ }^{16}$ Zob. M. Gennari, Trattato di pedagogia generale, Milano 2007, s. 214-215. 
czy też stwierdzić brak wartości we wszelkich antywartościach. W sposób uproszczony oczywiście możemy próbować przedstawić tę drogę czynienia pewnych wartości swoimi - czyli ich „podmiotowania”, posługując się jej analizą przeprowadzoną przez G. Corallo. Jego zdaniem, wszelkie dobro jako przedmiot pożądania naszej woli, jako upragnione przez człowieka, jest podmiotowane (to właśnie w tym znaczeniu mówimy o wartościach w sensie psychologicznym). Ta zaś interioryzacja obiektu (przedmiotu), poprzez którą rzeczywistość obiektywna wkracza w nasze $J a$, jest zarazem motywem tej identyfikacji. Nie jest ona też bezpośrednią przyczyną, dla której człowiek miałby działać, lecz staje się nią sam człowiek, który działa w taki właśnie sposób. W tym znaczeniu człowiek w procesie formacji, wychowania i kształcenia, zamienia aktem swojej wolnej woli otaczającą go rzeczywistość, w tym także wartości - wartościuje je i przejmuje kontrolę nad ich znaczeniem, czyniąc je swoimi ${ }^{17}$.

Człowiek utożsamiając się ze swoim działaniem, odsłania najpełniej nie tylko problem genezy wartości i ich systematyzacji, lecz także problem powstawania i formowania człowieka jako systemu wartości, stanowiących go niezależnie od danych przeżyć czy sytuacji egzystencjalnych aktualnych i konkretnych ${ }^{18}$.

Wychowując się, podmiot otwiera się następnie na dialog społeczny dotyczący wartości, wpisuje się w wielowymiarowość i międzypodmiotowość wartości, czyniąc tym samym miejsce tradycji, jak również mogąc ją przekraczać. Umożliwia to człowiekowi odpowiedzialność za cnoty i za wartości ${ }^{19}$. W taki też sposób życie, historia i świat mogą wychowywać człowieka do wartości, do harmonii, do uczuć, do cnót. A zatem człowiek może poszukiwać w formowaniu swojej ludzkiej istoty tej siły, która pozwoli mu na dominację nad okolicznościami, tendencjami, dyspozycjami, tak aby harmonia, uczucia, wartości i cnoty stały się kierującymi jego życiem, jego historią i jego światem.

W związku z taką sytuacją człowieka W. Goethe podkreślał ze swadą wieszcza, że ,wielką zasługą człowieka pozostaje dominowanie okoliczności, ale też i pozwolenie na zdominowanie się przez nie"20. Te słowa wskazują na fakt, że zarówno życie, jak i historia oraz świat, mogą wychowywać człowieka do wartości, do cnót, do harmonii, podobnie jak mogą też go cofać w rozwoju w związku z tymi wartościami (antywychowywać).

17 Zob. G. Corallo, Pedagogia, Vol. 1: L'educazione. Problemi di pedagogia generale, Roma 2010, s. 351.

18 Zob. tamże, s. 351-352.

19 Zob. M. Gennari, dz. cyt., s. 214.

${ }^{20}$ J. W. Goethe, Wilhelm Meisters Lehrjahre (1795-96), hrsg. E. Beutler, Berlin-Zürich 1948, s. 700. 
A zatem człowiek może szukać w formacji własnego człowieczeństwa siły do zdominowania okoliczności, tendencji i dyspozycji, aby harmonia, uczucia, wartości i cnoty stały się rządzącymi jego życiem, jego historią i jego światem. Cnoty bowiem nie są jakąś abstrakcją ponadhistoryczną, lecz efektem twórczości wolnej natury ludzkiej, którą tylko może kierować wola formacji, tak aby etyki cnót nie redukować do etyki norm ${ }^{21}$.

Tym samym, jak zauważa M. Gennari, człowiek jest wolny od podporządkowania zasadom moralnym narzuconym jemu przez instytucje, władze czy systemy, a ta jego wolność sięga aż tak wysoko, że może odizolować się od tego wszystkiego, co nie jest wartością związaną z jego odpowiedzialnością 22 .

\section{Czlowiek podmiotem wartościowania oraz podstawową zasadą aksjologii i teleologii wychowania - autoteliczność człowieka w wolności}

By jeszcze bardziej zrozumieć, wyjaśnić i uzasadnić celowościowe zorientowanie człowieka i tym samym przyjąć je za podstawę twierdzenia o konieczności celów w wychowaniu, należy wskazać na specyfikę myślenia i działania pedagogicznego, rozpostartego ciągle między stanem rzeczywistym a możliwym człowieka i społeczności. W pedagogice i w działalności wychowawczej znajdujemy się ciągle w sytuacji swoistego napięcia pomiędzy rzeczywistością a ideałami, pomiędzy stanem faktycznym a stanem upragnionym, co jest dowodem aksjologicznego charakteru zarówno działalności wychowawczej, jak również pedagogiki, a nawet poszczególnych tworzących ją dyscyplin. Oczywiście w ramach poszczególnych dyscyplin możemy zauważyć, że ich charakter metodologiczny zbliża się bardziej do rzeczywistości i ją poddaje badaniom, bądź też zbliża się bardziej do odkrywania jakiegoś stanu upragnionego i ideału wychowania. Są to dwa światy, które nie są jednakże do rozdzielenia, lecz które wielorako są ze sobą powiązane, ciągle współwystępując we wzajemnych interakcjach:

1) Świat faktów gromadzi przedmioty, zdarzenia, wzajemnie powiązane z procesem stawania się, jak i wymiarem konkretnego istnienia. Są one mierzalne, przewidywalne i powtarzalne. Ten świat jest najbardziej też wpisany w rzeczywistość podlegającą naukowym badaniom, w wyniku których poszczególne fakty są rejestrowane i mierzone, a następnie - w oparciu o uzyskane wyniki - wyprowadzane są podstawowe prawidłowości i typologie.

${ }_{21}$ A. Ch. MacIntyre, After Virtue. A Study in Moral Theory, London 1981.

${ }^{22}$ Zob. M. Gennari, dz. cyt., s. 215. 
Powstają w ten sposób różne rodzaje wiedzy o różnych poziomach abstrakcji (włącznie z tą filozoficzną i teologiczną, zatrzymującymi uwagę na faktach egzystencji i na przykład na teologii rzeczywistości ziemskich), określanej często jako „naukowa”. Często jest to koncentracja całej uwagi na wymiarze ilościowym badanej rzeczywistości (badanych faktów) i na jej wymiarze postrzegalnym zmysłami ${ }^{23}$.

2) Zdajemy sobie jednak sprawę, że sama nawet rzeczywistość wymyka się temu wymiarowi faktów, odsłaniając złożoność wszystkiego, co nas otacza. Wymiar faktów i egzystencji nie wyczerpuje bogactwa rzeczywistości, wobec której ukazuje się także jej wymiar idealny. W ten sposób, poza tym, co stanowi rzeczy i fakty, znajduje się to coś, na co nie potrafią odpowiedzieć dyscypliny, zatrzymujące swoją uwagę na wymiarze faktów. Sama już przyczynowość tych faktów, ich - dlaczego? prowadzi do analizowania dogłębnych wewnętrznych uwarunkowań tychże samych faktów. W taki sposób pojawiają się innego rodzaju fakty, takie jak: dobro i zło, moralność i wolność, celowość i pragnienie, motywy i zasady, którymi kieruje się człowiek jako podmiot. Wraz z nimi dochodzą do głosu wartości, jako wewnętrzna racja tych faktów, czyniąca je właśnie wartościami ${ }^{24}$.

Takie stwierdzenie może jednak rodzić przekonanie, że wartości po prostu nie istnieją a cały świat, także ten ludzki, byłby jedynie nędznym odbiciem i cieniem czegoś doskonałego. W związku z powyższym zaznacza się potrzeba hierarchii wartości, według której wychodząc od Absolutu, przechodzimy przez różne poziomy istnienia przejawiające się jako wartość w kontekście Absolutu. Samo istnienie tych rzeczy, poza wymiarem faktu, przedstawia wartość i wymyka się jakimkolwiek podejrzeniom o przypadkowość.

$\mathrm{W}$ tym sensie św. Bonawentura przedstawia w swoim wędrowaniu ludzkiego myślenia ku Bogu tę drogę, poprzez którą człowiek zmierza do swojego zjednoczenia z Bogiem, powraca do Wartości Absolutnej, przechodząc przez kolejne stopnie istnienia (doskonałości). W tym też znaczeniu każdy byt, nawet jeśli nie w wymiarze absolutnym, posiada wartość przez sam fakt jedności istnienia. W teologii katolickiej (w dogmacie $O$ Stworzeniu) zakłada się, że Bóg stwarzając byty, daje im własne ich istnienie, a nie jedynie emanuje siebie (jak chciałby na przykład Plotyn). Zanegowanie tej

${ }^{23}$ Zob. G. Corallo, dz. cyt., s. 352-354.

${ }^{24}$ Tego właśnie aspektu uczestnictwa nie dostrzegł Arystoteles, który wyłączył Absolut z tego świata, aby go nie kalać. Tymczasem w Absolucie egzystencja utożsamia się z esencją w absolutnej zwyczajności możliwej dla Absolutu (zob. G. Corallo, dz. cyt., s. 355-356). 
zasady sprowadzałoby na nas w prostej linii koncepcję panteistyczną rzeczywistości ${ }^{25}$.

3) W tym zakresie istnieje jednak jeszcze trzecia kategoria wartości, znajdujących się między Absolutem a wartościami poszczególnych stopni istnienia. Jest ona całkowicie związana z człowiekiem i jego egzystencją chodzi mianowicie o wartość wolności, bez której człowiek nie tylko byłby pozbawiony wartości najwyższych, ale wręcz okaleczony w związku z byciem tym, kim powinien być, a nie jest. Braki w zakresie specyficznych wartości ludzkich, a zatem tego, jakim człowiek powinien być, wywołują degradację tak zwanych wartości kulturalnych, historycznych, naukowych, a nawet samego postępu technicznego i społecznego, do poziomu zwykłych faktów. Historia stawałaby się czymś w rodzaju jedynie historii naturalnej rodu ludzkiego, jako fauny świata, tracąc wymiar człowieczeństwa. Zdobycze techniki przyjęłyby formę środowiskowej adaptacji i tresowania postaw, a te kategorie byłyby najwyższym możliwym ,wyjaśnieniem” postawy ludzkiej jako wpisanej w pewną prawidłowość zdarzeń. Oczywiście na takich podstawach nie mogłaby oprzeć się ani etyka, ani pedagogika ${ }^{26}$.

Negacja wartości przybiera obecnie wielorakie formy odzwierciedlające zresztą wielorakość wysiłków identyfikowania wartości z różnymi aspektami rzeczywistości ${ }^{27}$. Mało logiczny jest też pogląd, że wartości (na przykład bohaterstwo czy rozumność) zależą od znaczenia nadawanego przez daną sytuację, gdyż jeśli znaczenie ma swoje osadzenie w strukturze bytowej, rzeczy zachowują swoje takie samo znaczenie w różnych sytuacjach. Budzi wątpliwości również stanowisko egzystencjalizmu w odniesieniu do wartości ze względu na dużą dozę irracjonalizmu tam zawartego. Pierwszeństwo przyznawane egzystencji nad istotowością mogłoby oznaczać, że wartość zewnętrzna istnieniu mogłaby być motywem własnej egzystencji.

Tak zatem koncepcja hierarchii wartości wyżej już ukazywana pozwala uznawać wartości bez potrzeby ich absolutyzowania, ale też uznać ich własną wartość osadzoną ontologicznie. Na tej linii między realnością a ideałem plasuje się sam człowiek, który staje się zasadą i podstawą realizacji określonej koncepcji wartości.

${ }^{25}$ Zob. tamże, s. 356-357.

${ }^{26}$ Zob. tamże, s. 358-359.

${ }^{27}$ Oczywiście dzisiaj już tylko zdziwienie może wywoływać opinia o ewolucyjnym rozwoju wartości na bazie zachowań instynktowych, gdyż w związku z wartościami, jak to zresztą wykazywał J. Dewey, chodzi przecież o zrelacjonowanie wartości do rzeczywistości, a nie o wykazywanie jak ludzie doszli do ich poznania. (Zob. J. Dewey, J. H. Tufts, Ethics, New York 1932; J. Dewey, Problems of Men, New York 1946; zob. także G. Corallo, dz. cyt., s. 359). 
Sam człowiek staje się w ten sposób twórcą wartości, gdzie doświadczenia sukcesów i rozczarowań, moralności i wolności, zwycięstw i zdobyczy pozwalają na nabywanie wartości w procesie przyjęcia zewnętrznego ideału i uczynienie go wewnętrzną formą osoby (S. Kunowski w tym sensie mówi o introcepcji wartości $)^{28}$. W istocie człowiek nie stanie się twórcą wartości, jeśli najpierw nie stanie się stworzeniem bogatym w wartości, przyswajając je sobie w ustawicznym wysiłku wychowawczym, formacyjnym czy kształceniowym $^{29}$. W tym znaczeniu Katarzyna Olbrycht mówi o możliwościach edukacji aksjologicznej, której celem jest zwiększanie kompetencji związanej ze znajomością problematyki wartości i wartościowania oraz podejmowania świadomych, samodzielnych aksjologicznych decyzji ${ }^{30}$.

Już powyższe stwierdzenia wyraźnie wskazują na konieczność problematyki celów w pedagogice oraz nieodzowność celu w każdego rodzaju działalności o charakterze wychowawczym. Świat wartości wyraża to, co powinno być, a w związku z tym wymaga zobowiązania się i poświęcenia, czasami aż do granic prawdziwego heroizmu. Miłość wartości pozwala ludziom wyrywać się z przeciętności i pozostawać otwartymi na wyzwania życia, jak również tworzyć historię. Właśnie historia odzwierciedla dążenia ludzkie, aspiracje, sukcesy pod tym względem, jak również niepowodzenia i ponowne próby osiągania wartości. Można za G. Corallo powiedzieć, że nie ma historii, w której nie byłoby wartości, ale też nie ma wartości bez wolności, a wraz z nią przychodzi sumienie, odpowiedzialność, zobowiązania i zadania moralne ${ }^{31}$.

Wychowanie jest wprowadzaniem i swoistym osadzaniem człowieka jako uczestnika i aktora tych zdarzeń i tej historii. Jeśli zgadzamy się z tym stwierdzeniem, jako oczywistym stanem rzeczy, to już ono w samym sobie ukazuje, że wychowanie nie może się pozwolić zredukować do jednego z biegunów: albo indywidualność, albo życie zbiorowe, lecz konieczne są oba. Podobnie człowiek nie może pozostawać zamknięty w samym sobie, lecz otwarty na obiektywny świat wartości, który powinien najpierw poznawać, następnie uznać i go sobie przyswajać. Szczególna rola przypada w tym dziele wychowawcy, który pokazuje te wartości wychowankowi, ale też w swoim życiu je realizuje, czyni wrażliwym na nie wychowanka i do nich wychowuje.

${ }_{28}$ Zob. S. Kunowski, Wartości w procesie wychowania, Kraków 2003, s. 17.

29 Zob. G. Corallo, dz. cyt., s. 361-362.

${ }^{30}$ Zob. K. Olbrycht, Prawda, dobro i piękno w wychowaniu czlowieka jako osoby, Katowice 2000, s. 95n.

${ }^{31}$ Zob. G. Corallo, dz. cyt., s. 362-364; zob. także M. Musaio, Pedagogia della persona educabile. L'educazione tra interiorità e relazione, Milano 2010, s. 32n. 
Jest taki moment, który znajduje się między poznaniem a decyzją (czy też wyborem) - jest nim rozpoznanie i uznanie wartości obiektywnych, zewnętrznych, teoretycznych - jako wartości własnych, osobowych, jako nabycie upragnione i godne, jako wstęp do ,ja” lepszego. Uwarunkowania i przyczynowość wychowania zmierzają wyraźnie do takiej właśnie interioryzacji wartości, w której dokonałaby się transformacja i interioryzacja wartości, przemieniając nasz sąd teoretyczny o danej rzeczy na sąd praktyczny i aktywny. Temu właśnie procesowi G. Corallo nadaje nazwę wartościowania ${ }^{32}$. Istotę tego procesu ujmują różne dyscypliny, między innymi z pozycji psychologicznej Jadwiga Puzynina uważa ten proces za czynność w zasadzie psychiczną człowieka, ,polegającą na stwierdzaniu, jakie (i w jakim stopniu) wartości pozytywne i negatywne właściwe są - zdaniem osoby wartościującej - danym cechom, zachowaniom, stanom rzeczy, a pośrednio przedmiotom" ${ }^{33}$. W taki sposób, jak zauważa Maria Tyszkowa, w procesie wartościowania ma miejsce swoiste „odniesienie doświadczeń indywidualnych do systemu wartości (ich opracowanie w systemie ewaluatywnym)" ${ }^{\prime 34}$, a możemy ten proces określać też wartościowaniem lub ewaluacją doświadczenia. Tego rodzaju wartościowanie i wychowanie do niego zawsze ma miejsce w procesach socjalizacji, nauczania i wychowania ${ }^{35}$, co zarazem wskazuje na ich „nieuniknione uwikłanie” w problematykę celów.

Obecność wartości w sensie podmiotowym i psychologicznym jest rzeczą normalną w odniesieniu do każdego podmiotu i należy ją odróżnić od istnienia wartości w sensie obiektywnym. Poza tym należy zauważyć, że każdy podmiot jest ukierunkowany na wartości, a zatem obecność jakiejkolwiek interesowności w tym przypadku należałoby uważać za głęboką patologię. Takie zaś wartości (podmiotowe i psychologiczne) jedynie przypadkowo mogą się odnosić do wartości obiektywnych i odzwierciedlają dążenia jednostki związane z przedmiotami. Tak zatem wartość obiektywna nie oznacza tym samym wartości psychologicznej i może pozostawać poza zasięgiem zainteresowań $J a$ osobowego i jego osobowych wartości. Natomiast wartością podmiotową i psychologiczną staje się to wszystko, czego jednostka chce i pragnie, o ile to uznaje jako swoją wartość ${ }^{36}$.

${ }^{32}$ Zob. G. Corallo, dz. cyt., s. 364.

33 J. Puzynina, Język wartości, Warszawa 1992, s. 83.

${ }^{34}$ M. Tyszkowa, Jednostka a rodzina: interakcje, stosunki, rozwój, w: M. Przetacznik-Gierowska, M. Tyszkowa, Psychologia rozwoju czlowieka, t. 1: Zagadnienia ogólne, Warszawa 1996, s. 127.

${ }^{35}$ Zob. M. Nowakowska, Nowe idee w naukach społecznych, Wrocław-Warszawa-Kraków-Gdańsk 1980, s. 357.

${ }^{36}$ Zob. G. Corallo, dz. cyt., s. 365. 
Działalność wychowawcza związana z wartościowaniem i wychowaniem do wartościowania zmierza do potwierdzenia i doprowadzenia do więzi między wartościami ujętymi w sensie psychologicznym danego podmiotu a wartościami obiektywnymi i to w taki sposób, aby żadna $\mathrm{z}$ wartości obiektywnych, jaka powinna zaistnieć w człowieku z jakiegokolwiek powodu, nie była nieobecna w wychowanku, a z drugiej strony, aby wszystkie wartości psychologiczne w nim obecne miały jakąkolwiek więź z wartością obiektywną, przynajmniej w jakimś sensie ogólnym, przyjmując w taki sposób aspekt moralny i oświecając świadomość podmiotu światłem moralności ${ }^{37}$. Miałoby to tak przebiegać, aby tym światłem moralności tak oświecać, aby nie pozostała żadna część ciemna podmiotu wykluczona od tego światła moralności, aby nie dopuścić do niekontrolowanych i niebezpiecznych sfer cienia całkowicie w zasięgu instynktu i impulsu w stanie czystym ${ }^{38}$.

Tak możemy sformułować tezę, że najwyższa zasada postępowania wychowawczego powinna polegać na promowaniu w wychowanku zdolności wartościowania spotykanych i doświadczanych dóbr i ideałów, jakie wychowawca powinien i chce jemu przybliżyć. Wiemy też, że dla skuteczności takiego celu staje się ważna osobowość wychowawcy, którego autorytet, postawa będąca personalnym symbolem wartości, może stawać się niepowtarzalnym źródłem doświadczania wartości wychowawczych. Od tej zasady pochodzą wszystkie inne ogólne zasady metody wychowawczej.

Tak zatem odsłania się nam ogromna subtelność pracy wychowawczej, poprzez którą, wpisując obraz wartości w wychowanka, faktycznie tworzymy jego osobowość. Powinna tu bowiem dominować wskazywana już wyżej obiektywność wartości, a nie osobowość lub upodobania wychowawcy, jak również sam wychowawca powinien zachować dużo rozwagi, by nie uznawać za normalne takich czy innych skłonności wychowanka, z jakimi powoli się odsłania. Poza tym całą pracę wychowawczą należałoby realizować pod znakiem wolności od jakiegokolwiek doktrynerstwa, stereotypów, także ideologii liberalnej - zwykle dość dalekiej od prawdziwej wolności.

Akt wartościowania powinien być zawsze aktem moralnym, wspieranym przez sumienie wychowanka i nie powinien być nigdy podyktowany wymogiem jakiejkolwiek współczesnej „drobnomieszczańskiej poprawności”, zamieniającej wychowanie w pełnym tego słowa znaczeniu na tresurę. Wymaga zatem dokładnej analizy dogmat J. J. Rousseau podjęty zbyt naiwnie i ideologicznie przez wiele współczesnych koncepcji wychowania liberalnego, który faktycznie, jak zauważył to zresztą G. Corallo, nawołuje do wyzwolenia się człowieka od siebie samego. Oczywiście jakaś norma

37 Zob. K. Olbrycht, dz. cyt., s. 71-87.

${ }^{38}$ Zob. M. Musaio, dz. cyt., s. 66n. 
moralna może być niewygodna dla kogoś, ale wówczas pozostaje też bardzo pomocny fakt, że inni ją zachowują i że nie jest ona możliwa do oddzielenia jej od człowieczeństwa ${ }^{39}$.

Zdaniem przywoływanego już G. Corallo, wartościowanie rozwija się w zasadzie wokół dwu pól, widzianych jako czynniki wychowania:

1. respekt okazywany wychowawcy, wskazujący na jego oddziaływanie swoim przykładem powodującym jego określone działania w taki sposób, aby przedstawiane wychowankowi wartości mogły się zrodzić w wychowanku;

2. respekt wobec wychowanka jako podstawowy wymóg wywołania jego własnej aktywności ${ }^{40}$.

Rezultatem wychowania ma się stać aktywne i moralne wprowadzenie wychowanka w świat, gdy rozpozna on samego siebie jako związanego $\mathrm{z}$ działaniem na rzecz samego siebie $\mathrm{i}$ innych, także dla Boga i ludzi historii i gdy to wszystko umieści w relacji do realizowania samego siebie. Jest tu nieodzowna pewna świadomość historyczna, przedstawiająca najwyższy cel wychowania, w którym rozszerza się osobowość człowieka, który nie zatracając się, staje się właśnie osobą. Jeśli świat nie jest ogołocony z wartości, jeśli w tym procesie nie zabraknie wytyczania sobie celów, nie ma sprzeczności między światem a $J a$ - o ile jest ono ujęte w tej głębokiej perspektywie moralnej. Wówczas wyłania się swoiste powołanie osoby do realizowania postępującego stwarzania świata i ubogacania go wartościami, aktywnego wpisywania się w historię nie tyle ujętą jako rejestracja faktów, lecz właśnie jako res gestarum - ideowo ujętą narrację dziejów ${ }^{41}$.

Można też jeszcze inaczej spojrzeć na wartości, a mianowicie, że są one w pewnym sensie ,zaraźliwe”, są one też dogłębnie chrześcijańskie, jeśli przyjąć znane stwierdzenie, że chrześcijaństwo powstało, aby człowieka uczynić realizującym dobro a swoje życie służbą. W sumie istnieje w świecie cała masa wartości, ale niestety zbytnie zainteresowanie się „faktami” (naukowymi, ekonomicznymi, jeszcze innymi) czyni ten świat ubogim w wartości, których po prostu się nie dostrzega. Aby je umieć odkrywać i nimi żyć, jest potrzebne właśnie wychowanie i wyraźnie też je nazwijmy - wychowanie do wartościowania ${ }^{42}$.

W centrum tego procesu i najwyższej rangi wartością jest sam człowiek. Stawiając człowieka w centrum naszej refleksji związanej z celowo-

39 Zob. G. Corallo, dz. cyt., s. 366.

${ }^{40}$ Zob. tamże, s. 367.

${ }^{41}$ Zob. m.in. mój artykuł tę problematykę podejmujący w związku z pracą naukową prof. dr hab. Stanisława Litaka, w: P. P. Gach, M. Surdacki (red.), Vir honestus ac bonus. Stanistaw Litak 1932-2010, Lublin 2011.

${ }^{42}$ Zob. G. Corallo, dz. cyt., s. 367-368. 
ścią wychowania, przypisujemy człowiekowi tę wartość i znaczenie, które często jest wyrażane kategorią „humanizm”. W tym sensie sięgamy do tych źródeł humanizmu, które opierają się na fakcie nade wszystko godności człowieka ${ }^{43}$.

Powołując się na wykładnię normy personalistycznej dokonaną przez Karola Wojtyłę, wskazującego na osobę jako takie dobro, na które właściwą odpowiedzią może być tylko kochanie jej ${ }^{44}$, Peter J. Colossi wskazuje na niekomunikowalność właśnie doświadczenia każdej osoby, które sprawia, że kochamy tę osobę i podziwiamy. Przez działanie w wolności, przez spotkanie z drugim objawia się niepowtarzalność osoby, którą kochamy i to objawia i potwierdza fakt, że wartość osoby nie może być zastępowalna - jest niepowtarzalna ${ }^{45}$.

Godność i siła naszego człowieczeństwa gwarantują istocie ludzkiej możliwość formowania siebie we własnym myśleniu. Autentyczna wolność myślenia, jaka przynależy człowiekowi, może być jednak łatwo zagrożona przez przynależność do ideologii, szkół, ruchów, tendencji, prądów, grup czy akademii itp. Może się stać zatem i taka sytuacja, że nie dojdzie do głosu autentyczne myślenie ludzkie, które jest koniecznym warunkiem wychowania posiadającego duchową naturę. Wychowanie człowieka nie może być wiązane tylko z genetyką i wrodzonymi cechami - najwyżej wspieranymi przez wychowawcę, ani też postrzegane jako poddane wyłącznie oddziaływaniom zewnętrznego środowiska i swoistemu urabianiu. Rozwojowy charakter całej egzystencji człowieka jest teleologiczny i w konsekwencji otwarty na cały otaczający świat, oczywiście w sposób ukierunkowany. Oznacza to pracę i stały wysiłek człowieka dotyczący zmierzania ku czemuś - aktywność rozpostartą pomiędzy sobą aktualnym a sobą możliwym. Człowiek jest efektem wpływu kultury, a nie tylko tego, co przynosi ze sobą w momencie urodzin. Wychowanie zatem długo uczestniczy w ustawicznym procesie stawania się człowieka i staje się przez to procesem natury nade wszystko duchowej ${ }^{46}$.

${ }^{43}$ Zob. H. A. Bedau, Justice and Equality, New Jersey 1971, s. 5-6.

${ }^{44}$ Zob. K. Wojtyła, Osoba i czyn oraz inne studia antropologiczne, Lublin 2000, s. 198 199. Odsyłam też do moich prób ukazania pedagogicznego ujęcia „normy personalistycznej”: 'Norma personalistyczna' w edukacji, w: Z. Uchnast (red.), Norma psychologiczna. Perspektywy spojrzeń, Lublin 1997, s. 90-100; tenże, Znaczenie 'normy personalistycznej' w działalności wychowawczej, w: J. Kostkiewicz (wybór tekstów), Wprowadzenie do pedagogiki ogólnej, Stalowa Wola 1997, s. 187-215.

${ }^{45}$ P. J. Colosi, Personal correspondence with Ashley K. Fernandes, w: A. K. Fernandes, Euthanasia, assisted suicide, and the philosophical anthropology of Karol Wojtyla, Rozprawa doktorska (Ph. D. Thesis), Washington 2008, s. 191.

${ }^{46}$ Zob. O. Fullat, I. Genis, Sens et éducation, w: J. Houssaye (dir.), Éducation et philosophie. Approches contemporaines, Paris 1999, s. 202. 
Ludwika Jeleńska w tym właśnie rozumieniu wychowania wskazuje na potrzebę wpisywania w świadomość wychowanka pewnych wartości, które inspirowałyby go w działaniu. Autorka ta dostrzega w tym zakresie trzy zadania: 1) dostarczenie wychowankowi odpowiednich wartości; 2) wytworzenie możliwości samowychowawczych; 3) umocnienie możliwości kierowania sobą ${ }^{47}$. W istocie możemy je sprowadzić do ukierunkowania wychowanka na cel czy też cele.

W tym sensie należałoby odkrywać nade wszystko wartości, dzięki którym wola ludzka mogłaby się jeszcze bardziej zobowiązywać do działania. Prawdziwym zaś aktem ludzkim byłby ten, który określamy jako duchowy, wyrażający się w postaci przeżywania wewnętrznej potrzeby wolności i aktywizujący się w sytuacjach spotkania się z tym wszystkim, co tę wolność ogranicza, powiększając zarazem progresywnie sfery swojego wpływu. W tym też sensie możemy stwierdzić, że prawdziwe wychowanie rodzi się po to, aby kiedyś obumrzeć. Wychowanek bowiem nabywa coraz większej wolności, poszerza jej zakresy, a wychowawca nie powinien mu tego procesu uniemożliwiać ani też w jej osiągnięciu przeszkadzać, lecz kreatywnie proces ten wspierać ${ }^{48}$.

Powstaje jednak poważna trudność związana z dążeniem podmiotu do wolnego i autentycznego wyrażenia się w swojej indywidualnej tożsamości, związana z odgórnym i zdecydowanym odrzuceniem tego wszystkiego, co nie posiada tak zwanej „oczywistości naukowej”. W tym względzie na przykład u L. Jeleńskiej wkracza obok świadomości i ukierunkowanego dążenia do celu również problematyka podświadomości, gdy stwierdza, że „,to właśnie ciemne i ukryte jest najczęściej przyczyną kierunku naszego życia, naszego działania, sposobu reakcji"49.

Zarówno wpływy świadome, jak i te - nieświadome przenikają do wnętrza człowieka i kodują się w podświadomości, aby w konkretnych, sprzyjających momentach uzewnętrznić się. W tym sensie Jeleńska włącza do wychowania to wszystko, co przekształca się w wewnętrzne motywy w psychice wychowanka, co przyjęte jako własne, słuszne lub konieczne, pozwalając wychowankowi na postępowanie zgodne z normami środowiska. Dokonywałoby się w ten sposób swoiste zaszczepienie jednostce „drugiej natury”, w którym jednostka wpisuje się w swoją kulturę, swoją społeczność i w całe życie społeczne, w zwyczaje, obyczajowość, wartości i cele - te jednak są odbierane przez każdego na swój sposób i wyrażają się w działaniu, o któ-

${ }^{47}$ Zob. L. Jeleńska, Sztuka wychowania, Warszawa 1930, s. 32.

${ }^{48}$ Zob. L. Secco, Dall'educabilità all'educazione, Verona 1990, s. 99-100.

${ }^{49}$ Zob. L. Jeleńska, dz. cyt., s. 38. 
rym Jeleńska stwierdza: „Jasne pojęcia służą do mówienia, lecz działamy zazwyczaj poprzez nieprześwietlone, mgliste. One życiem władną"50.

Od XIX wieku zaznacza się wielka różnorodność podejść do zagadnienia istoty ludzkiej: od idealizmu niemieckiego, traktującego człowieka jako absolutny rozum, aż po ujęcia nauk szczegółowych, zwłaszcza humanistyki, naturalizmu i ewolucjonizmu. Owocowały one niejednokrotnie uproszczonymi koncepcjami człowieka i w konsekwencji koncepcjami wychowania. Jak zauważa natomiast Benedykt XVI, „żeby wychowywać, trzeba wiedzieć, kim jest osoba ludzka i znać jej naturę" (CV 61) ${ }^{51}$.

Ukierunkowanie się współczesnych pedagogów jedynie na aspekty biologiczne wychowania lub też psychologiczne, bądź wreszcie społeczne lub tylko kulturowe, może prowadzić do zatracenia tej głębi człowieka, którą zwykli jesteśmy nazywać w chrześcijaństwie - duchowościa. Sprowadzamy wówczas także w dziedzinie wychowania ostatecznie wszystko bądź to do czynników wrodzonych (genetycznych), bądź to do zewnętrznych wpływów i bodźców środowiska otaczającego - popadając ponownie w zagrożenie jedynie dwuczynnikowej teorii wychowania. Byłoby to przeoczeniem tej rewolucji (zwanej przecież rewolucja ducha, jaką wniosło chrześcijaństwo) i pomijałoby to ten czynnik wychowania, jakim jest czynnik osobowy - duchowy.

To do tych tendencji odnosił się Benedykt XVI w encyklice Caritas in veritate, wskazując na niebezpieczne redukcje, u podstawy których

leży głębokie niezrozumienie życia duchowego, a prowadzą one do niedostrzegania, że rozwój człowieka i narodów zależy również od rozwiązania problemów o charakterze duchowym. Oprócz wzrostu materialnego, rozwój powinien również obejmować wzrost duchowy, ponieważ osoba ludzka stanowi 'jedność cielesną i duchową', zrodzoną ze stwórczej miłości Boga i przeznaczoną do życia wiecznego. Człowiek rozwija się, gdy wzrasta duchowo, gdy jego dusza zna samą siebie oraz prawdę, której zarodek Bóg w nim umieścił, gdy prowadzi dialog z samym sobą oraz ze swym Stwórcą (CV 76).

W Zakończeniu encykliki, w numerze 78, Benedykt XVI podkreśla:

Ideologiczne zamknięcie się na Boga oraz ateizm obojętności, zapominające o Stwórcy i narażone na zapominanie również o wartościach ludzkich, jawią się

${ }^{50}$ Zob. tamże, s. 38.

${ }^{51}$ Benedykt XVI, Encyklika Caritas in Veritate o integralnym rozwoju ludzkim w miłości i prawdzie, Kraków 2009 - w tekście CV z odnośnym numerem. 
dziś pośród największych przeszkód w rozwoju. Humanizm wykluczający Boga jest humanizmem nieludzkim. Jedynie humanizm otwarty na Absolut może nam przewodzić w krzewieniu i realizacji życia społecznego i obywatelskiego w obrębie struktur, instytucji, kultury i etosu - ratując nas przed ryzykiem, że staniemy się zakładnikami przelotnej mody.

Z takiej sytuacji najbardziej skutecznie wyprowadza człowieka ukierunkowanie się na cel i wytrwałe dążenie do niego. Obecność celu w procesie wychowania czyni zatem w ogóle możliwym sam proces wychowania, jak również stawanie się podmiotem, osiąganie dojrzałości i nade wszystko urzeczywistnianie siebie, albo inaczej „wyistaczanie się człowieka” w jego człowieczeństwie. Ten proces nie byłby możliwy bez celu, niemożliwe jest zatem mówić o wychowaniu i pokrewnych procesach bez celu.

\section{Upbringing without Goals? (Summary)}

Human existence is specific in that it involves upbringing based on setting goals, which people attain or strive to attain over a shorter or longer period of time. Such goals are necessary for people and their upbringing. Many contemporary concepts of human existence emphasize this goal-oriented human nature. For instance, Alfred Adler's individual psychology includes a theory that our goals influence our life plan and lifestyle.

Goal-oriented human nature seems to be in harmony especially with the specificity of pedagogical thought and action, spread continually between the actual state and the possible state of man and community, in a kind of a tension between reality and ideals, between the actual state and the desired state (axiological outline of upbringing, pedagogy and its individual disciplines).

While on the one hand we have the actual state of a person and their surrounding reality, we also need the ideal dimension as well as the third category, that is the values that are between the Absolute and the values of the various stages of existence, which find their fulfillment in the value of freedom, without which man not only would not be able to possess the highest values, but he would also remain crippled as a result of being who he should be, not who he actually is. It is the value of freedom that makes man become the creator of values in the process of adopting an external ideal and making it the inner form of a person (introception of values).

The presence of goals in the process of the act of education makes it possible, as well as causes outcrop or exteriorization of man himself in his humanity. 